\title{
Commons Governance Workshop: Michel Bauwens of the P2P Foundation
}

\author{
Sponsored by \\ Global Communication M.A. Double Degree Program
}

\section{Thursday, March 17, 10:00am to noon, Vancouver Harbour Center Campus Room 2250}

* Limited seats. First come, first served.

Join us for a mind-expanding workshop in commons governance by the international peer-to-peer innovator Michel Bauwens, helping us solve practical problems in designing institutions to meet the challenges of the coming decades.

In this workshop, Michel Bauwens (https://twitter.com/mbauwens), the founder of the P2P Foundation (http://p2pfoundation.net/Main_Page) and a co-founder of the Commons Transition Platform (http://wiki.commonstransition.org/wiki/Main_Page), will share his knowledge and analysis of the core issues in commons-based pathways for generating economic and social innovation.

Michel will present on the basic problems and principles in commons governance design, emerging tools such as innovative intellectual property licences and blockchain technology, and case studies from Spain, New Zealand and virtual transnational spaces.

After an initial presentation, Michel will work with participants for about 45 minutes to collectively analyse, critique and generate suggestions for the emerging issues of an Australian start-up: the Open Food Network (http://openfoodnetwork.org), a non-profit, open-source enterprise supporting local food initiatives globally.

Michel Bauwens is the Founder of the Foundation for Peer-to-Peer Alternatives (P2P Foundation) and the Head of Research for Commons Transition. He is a world-renowned peer-to-peer (P2P) theorist, academic, writer, researcher and conference speaker on the subject of new technology, digital media, culture, politics, governance, and social and economic innovation. Michel is a founding member of the Commons Strategies Group, Chair of the Technology \& ICT working group of the Hangwa Forum (Beijing, Sichuan), and Primavera Research Fellow at the University of Amsterdam. He advises Ouishare (Paris), Shareable magazine (San Francisco), Zumbara Time Bank (Istanbul), and ShareLex. He writes editorials for Al Jazeera English and Open Democracy, and co-authored the book Network Society and Future Scenarios for a Collaborative Economy with Valisis Kostakis (Palgrave Pivot, 2014). In 2014 he served as Research Director for the FLOK Society, which produced a Commons Transition Plan for the Government of Ecuador. He was also the lead writer and researcher for A Synthetic Overview of the Collaborative Economy (Orange Labs, 2014). 